Review

\title{
Cardiovascular Adaptations Induced by Resistance Training in Animal Models
}

\author{
S.F.S. Melo ${ }^{1,2}$, N.D. da Silva Júnior ${ }^{2}$, V.G. Barauna ${ }^{1}$, E.M. Oliveira ${ }^{2}$ \\ 1. Laboratory of Molecular Physiology, Health Sciences Center, Federal University of Espírito Santo. Address: Av. Marechal Campos, 1468 Maruípe, Espírito \\ Santo, Vitória, Brazil. Postal code: 29043900. Telephone number: (5527)996892407. \\ 2. Laboratory of Biochemistry and Molecular Biology of Exercise, School of Physical Education and Sport, University of São Paulo. Address: Av. Prof. Mello \\ Moraes, 65, Cidade Universitária, São Paulo, São Paulo, Brazil. Postal code: 05508-9000. Telephone number: (5511) 30913136. \\ $\square$ Corresponding author: Edilamar Menezes de Oliveira, Laboratory of Biochemistry and Molecular Biology of the Exercise. School of Physical Education and \\ Sport. Av. Prof. Mello Moraes, 65. Cidade Universitária, 05508-9000, São Paulo, SP, Brazil. Phone: 55-11-3091-3136, Fax: 55-11-3813-5921, E-mail: \\ edilamar@usp.br \\ (C) Ivyspring International Publisher. This is an open access article distributed under the terms of the Creative Commons Attribution (CC BY-NC) license \\ (https://creativecommons.org/licenses/by-nc/4.0/). See http://ivyspring.com/terms for full terms and conditions.
}

Received: 2017.10.03; Accepted: 2017.12.05; Published: 2018.02.12

\begin{abstract}
In the last 10 years the number of studies showing the benefits of resistance training (RT) to the cardiovascular system, have grown. In comparison to aerobic training, RT-induced favorable adaptations to the cardiovascular system have been ignored for many years, thus the mechanisms of the RT-induced cardiovascular adaptations are still uncovered. The lack of animal models with comparable protocols to the RT performed by humans hampers the knowledge. We have used squat-exercise model, which is widely used by many others laboratories. However, to a lesser extent, other models are also employed to investigate the cardiovascular adaptations. In the subsequent sections we will review the information regarding cardiac morphological adaptations, signaling pathway of the cardiac cell, cardiac function and the vascular adaptation induced by RT using this animal model developed by Tamaki et al. in 1992. Furthermore, we also describe cardiovascular findings observed using other animal models of RT.
\end{abstract}

Key words: resistance training; cardiovascular adaptation; animal model

\section{Introduction}

Resistance training (RT) was first described to induce skeletal muscle adaptations. Experimental models that try to mimic these adaptations in rats, use a model of chronic muscle stretching, compensatory overload and electric stimulation in unconscious animals. However, today it is surrounded by controversy if these models to induce skeletal muscle hypertrophy are similar to that promoted by RT in humans [1-3].

On the other hand, RT in conscious animals was created by some laboratories to improve its similarities to RT performed by bodybuilders. These models provide an excellent means to study both acute and chronic responses of RT in the muscles. However, these models still have the challenge of training the animals to voluntarily perform the traditional exercises performed by humans. In some cases, the animals are given food as a reward [4] or movement is stimulated by an electrical shock in the tail or leg, but not directly in the muscle tissue as in the previous unconscious animal models [2].

Tamaki et al., [2] created a model that mimics squat-training (figure 1) performed by humans, for rats and today it is the most common model used by many laboratories. The model was initially developed to compare metabolic and morphological adaptations in skeletal muscles in response to aerobic training and RT. After this first publication by Tamaki et al., other groups also used the same model to study the influence of RT in bone mass [5,6], in the metabolic processes [7] and in the body composition [8]. In 2005 our group were the first to use the same apparatus to examine the cardiovascular system and after that the number of studies using this model have grown to 
investigate the effects of the RT as non-pharmacological therapy for the treatment or prevention of the many different cardiovascular diseases [8-10].

Our first step was to perform the direct measurement of blood pressure (BP) and heart rate by a cannula inserted into the carotid artery. The cannula was connected to a polyethylene tube, and this to an electromagnetic transducer which was connected to an amplifier. From this, suing software, beat by beat values of systolic and diastolic blood pressure were obtained. Figure 2 is an example of a series of exercise. We can clearly observe the 12 pressure peaks corresponding to 12 repetitions performed, similar to weight lifters, that is characterized by the intermittent increase in BP during RT. In this context, our group began to investigate the effects of RT on the cardiovascular system in rats.

\section{Cardiac hypertrophy}

Cardiac hypertrophy $(\mathrm{CH})$ is a central feature in several scenarios of pathological and physiological remodeling [11,12]. It is well recognized, that intermittent increase in BP during RT leads to pressure overload to the left ventricle. This pressure overload stimulus increases cardiomyocyte cell width and left ventricular wall thickning. This $\mathrm{CH}$ features are observed in bodybuilders and named as physiological concentric $\mathrm{CH}$ [13]. On the other hand, pathological concentric $\mathrm{CH}$ is observed in heart subjected to different diseases such as hypertension or aortic stenosis, where there is a continuous pressure overload to the left ventricle. This type of $\mathrm{CH}$ is followed by diastolic and/or systolic dysfunction and an uneven increase in the thickness of the left ventricle posterior wall and interventricular septum

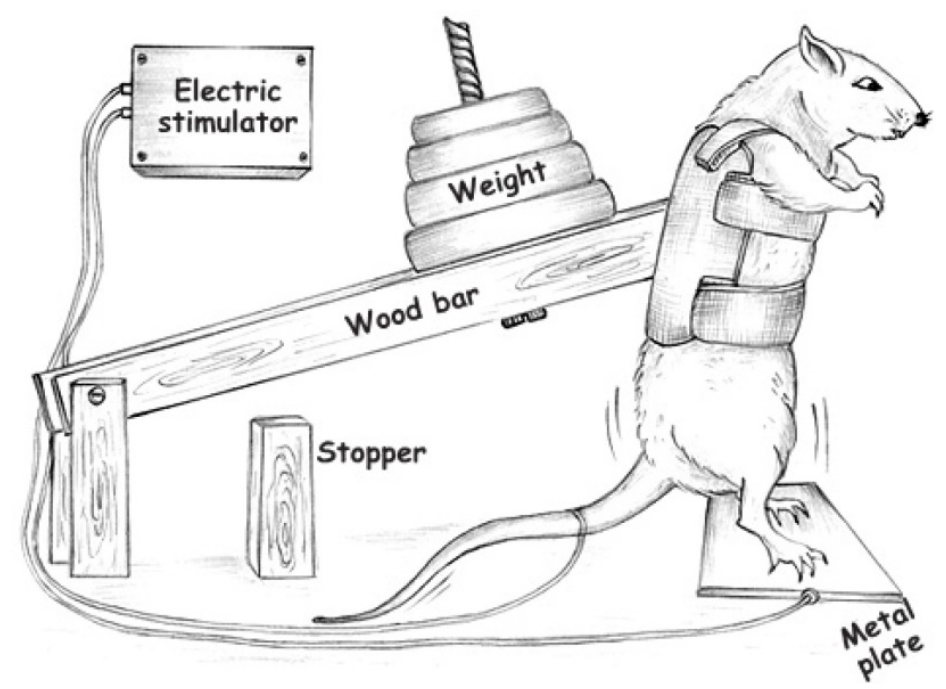

Figure 1: Apparatus used to perform resistance training. Adapted from Barauna et al, 2005 [17].
$[14,15]$. However, the physiological $\mathrm{CH}$ developed by high level strength athletes may present a macroscopic structure similar to pathological $\mathrm{CH}$, which could be incorrectly interpreted as pathological [16]. Therefore, here we will show our, and other authors results using the Tamaki Model about the morphological and molecular mechanisms responsible for physiological $\mathrm{CH}$ [2].

The results from our study [17], in 2005 demonstrated $\mathrm{CH}$ in rats in response to $\mathrm{RT}$. We observed $12 \%$ increase in the heats of trained rats which is similar to previous reported in human training for less than 3 months [18,19], but a smaller than described in other studies in humans engaged for more than 1 year in RT programs [13,20,21]. In another study, in 2007, Barauna et al., [22] found that the left ventricular mass assessed by echocardiography was $8 \%, 12 \%$, and $16 \%$ larger in the RT group, than in the control group in the first, second and third month respectively. This $\mathrm{CH}$ showed a similar increase in the interventricular septum and in the free posterior wall mass. There was no reduction in the end-diastolic left ventricular internal diameter during the 3 months of the RT period, showing that this stimulus leads to concentric $\mathrm{CH}$. In addition, our group also investigated the morphology of the cardiomyocyte isolated from the left ventricular after eight weeks of RT [23]. In this study we confirmed that RT resulted in an increase in both width and volume of left ventricular cardiomyocytes when compared to sedentary control animals. However, cell length was not affected by exercise sessions. Therefore, our data shows that RT model due to an increase in pressure overload in the heart during the exercise, induces concentric cardiac cells hypertrophy, which is in agreement with previous echocardiographic data from our group [22].

\section{Cardiac hypertrophy signaling pathway}

RT increases cardiac workload during the exercise sessions and thus it is an interesting in vivo model for studying physiological pressure overload on cardiac cells. It has become clear that external load is sensed by cardiac cells and converted into intracellular signals [14]. Among the possible mechanosensors one of the most studied is the angiotensin II type 1 receptor (AT1R). AT1R activates a wide spectrum of signaling responses which mediates BP control, thirst and sodium balance as well as diverse pathological actions in the heart, kidney, and other tissues [24]. It is well established that AT1R plays an important role 
in the development of $\mathrm{CH}$ in pathological conditions such as in cardiovascular and renal diseases. However, in 2008, Barauna et al., [25] demonstrated that AT1R blockade prevented physiological $\mathrm{CH}$ induced by RT in rats suggesting that the AT1R and its intracellular signaling also plays a role in physiological $\mathrm{CH}$ induced by RT. Furthermore, no changes were observed in the angiotensin II levels or in its producing enzymes angiotensin-converting enzyme I (ACE) and renin activities, but increased expression of cardiac AT1R, suggesting AT1R activation by mechanical stretch as previous described by us and other groups [26,27].

In fact, Zou et al., [26] were the first to show the AT1R as a mechanical sensor in cardiomyocytes and to activate hypertrophic signaling pathways upon mechanical stimuli in the absence of angiotensin II. In agreement, Frank et al., [28] reported that AT1R activation by mechanical stretch is responsible for modulating genes involved in cardioprotection, which most likely occurs because of the AT1R ability to activate G-protein independent pathways. Cardiac-specific over-expression of mutated AT1R knocked out of G-protein signaling presented a higher degree of $\mathrm{CH}$, but without fibrosis [29]. Zhai et al.,[29] also observed a reduction in apoptosis in the heart of these animals, corroborating the hypothesis that AT1R can activate pathways independent of G-protein, as in the case of exercise training, thus promoting physiological adaptations. In this regard, previous studies has suggested that AT1R may have beneficial effects, mainly thought $\beta$-arrestins, when it is biased activated to G-protein independent pathways [30]. Interestingly, in 2016, we highlighted that $\beta$-arrestin- 2 gene expression is increased in rats subjected to RT for eight weeks [31].

Additionally, reports have shown that physiological $\mathrm{CH}$ induced by aerobic training is associated to tyrosine kinase receptors activation and downstream PI3K/Akt/mTOR signaling pathway [32]. In fact, studies have shown that insulin-like growth factor -1 (IGF-1) is involved in protein

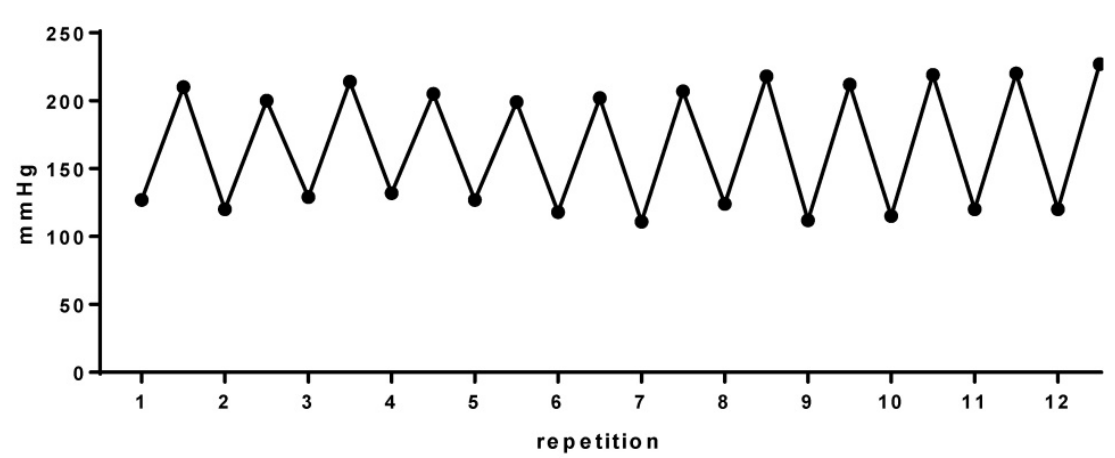

Figure 2: Blood pressure during 12 repetitions in a series of the resistance training in rats synthesis in physiological $\mathrm{CH}$ in both elite athletes [33] and trained rats [34]. However, Kim et al., [35] observed an unexpected increase in Akt phosphorylation even in trained IGF-1 receptor knockout animals also, suggesting that another pathway may be activated independent of the IGF-1 receptor. Interestingly, in 2011, we showed that a session of RT promoted increase in Akt phosphorylation 30 minutes after the RT session. This increased in Akt phosphorylation was also accompanied by an increase in phosphorylation of mTOR. However, these effects were blocked by blocking the AT1-R, suggesting activation of the AT1R-Akt-mTOR signaling pathway during a resistance exercise session as a potential mechanism for the $\mathrm{CH}$ [36].

Activation of MAPKs can also occur via G-protein pathway through adrenergic, endothelin-1, and AT1 receptors in animals subjected to pathological pressure overload (37). MAPKs are divided into 3 subfamilies on the basis of the terminal kinase involved in the pathway, namely: extracellular signal-regulated kinases (ERKs), P38, and c-Jun amino terminal kinase (JNKs). In an elegant study, Iemitsu et al.,[38] showed that cardiac ERK1/2 phosphorylation occurred 30 minutes after a session of aerobic exercise which decreased gradually with training adaptation (after 8 weeks of training). Similarly, Nakamura et al.,[39] showed that animals submitted to an exercise training protocol twice a week on a treadmill had increased ERK 1/2 phosphorylation, but with no signal of $\mathrm{CH}$. In this sense, in 2011, we showed ERK1/2 phosphorylation via AT1-R after a session of $\mathrm{RT}$, however, it is still unclear whether ERK $1 / 2$ is a critical mediator of hypertrophic response during RT. Furthermore, we also observed that P38 activation increased after 5 and 30 minutes of a resistance exercise session which was not inhibited by AT1-R blockade, suggesting another upstream signaling pathway or the activation of this MAPK other than AT1-R [31]. Although MAPKs signaling pathway studies predominate in the field of cardiovascular disorders, little is known about their role or expression patterns in physiological conditions, especially RT-regulated MAPKs.

\section{Cardiac Function}

RT was shown by Barauna et al., [22] to induce physiological stimulus for concentric $\mathrm{CH}$ without cardiac dysfunction in rats. Consistently, our results are in agreement with results in humans showing no cardiac dysfunction in resistance trained 
individuals $[18,20]$. Later, in 2015 , we observed that RT improved contraction and relaxation of isolated cardiomyocytes $[13,23]$. Although, not every possible mechanism had been tested, we showed at that time augmented expression of calcium regulatory proteins such as sarcoplasmic reticulum calcium ATPase-2a (Serca2a) in trained groups, which is responsible for $92 \%$ of $\mathrm{Ca}^{2+}$ reuptake $[40,41]$. We believe that this increased expression could at least partially explain the improved time to peak and time to half relaxation [13]. In this context, Pinter et al., [42] showed that in rats trained at $60 \%$ and $75 \%$ of 1RM there was an increase in the isometric force developed by the papillary muscles analyzed by the Langendorff technique. In this regard, the authors suggested that the improvement in cardiomyocyte contractility was due to increased myosin ATPase activity and enhanced $\mathrm{Ca}^{2+}$ influx after four weeks of RT. Furthermore, we showed that none of the pathological $\mathrm{CH}$ molecular markers such as atrial natriuretic peptide or a-MHC-to- $\beta$-MHC ratio were changed by $\mathrm{RT}$ in healthy rats $[13,25]$.

On the other hand, in rats with pathological condition, such as in spontaneously hypertensive rats (SHR), Fernandes et al., [43] showed that acute RT increased isometric force of papillary muscles in isolated perfused hearts, as well as increased functional activity of the sarcoplasmic reticulum but with no change in Serca2a and phospholamban proteins expression. Additionaly, Alves et al., [44] showed that 12-week of RT in chronic heart failure rats were able to improve cardiac function and attenuate left ventricular collagen volume fraction. Although, Doustar et al., [45] showed that 4 weeks of RT did not preserve heart remodeling after ischemia-reperfusion injury, evidenced by no change in the infarct size and apoptosis rate, Soufi et al., [46], showed that 12 weeks of the RT reduced the infarct size and provides cardioprotection against ischemia-reperfusion injury. Recently, in 2017, we reported that RT prevented cardiac interstitial collagen deposition and attenuated diastolic dysfunction in rats subjected to a high salt diet independent of alterations in blood pressure [47] and that low intensity RT for 10 weeks in streptozotocindiabetic rats induced an increase in systolic function and attenuation of cardiac autonomic neuropathy in diabetic rats [48]. Therefore, studies are still needed to understand the myocardial changes associated with RT in physiological and pathological situations.

\section{Vascular adaptation}

The effects of RT in the vascular system is still under investigation. A single session of aerobic exercise or RT reduces BP during the recovery period, which is called post-exercise hypotension (PEH). In normotensive subjects, the magnitude of the PEH has varied from $-4 /-2$ to $-14 / 4 \mathrm{mmHg}$ of systolic/diastolic BP $[49,50]$. In hypertensive patients, it has been reported PEH from $-12 /-6$ to $-23 /-14$ $\mathrm{mmHg}$, which is greater than the reduction observed in non-hypentensive subjects [51]. It is well established that exercise intensity (lower intensity promotes greater $\mathrm{PEH}[52,53]$ and volume (higher volume promotes greater $\mathrm{PEH}$ [54] are two determinants of $\mathrm{PEH}$, however, endothelial function and autonomic mechanism of PEH is poorly understood after RT.

The PEH has been associated with improved nitric oxide (NO) synthesis, leading to a reduction in the peripheral vascular resistance $[42,55]$ as well as reduction in the sympathetic nerve activity. In a study with SHR, both systolic and diastolic BP were decreased by -57 and $-25 \mathrm{mmHg}$ after 10 minutes of RT compared with pre-exercise values. PEH was abolished by L-arginine methyl ester (L-NAME) infusion, and the response to a-adrenergic stimulation in femoral artery was reduced due to buffering of $\mathrm{NO}$ after RT [55], suggesting $\mathrm{PEH}$ is mediated by increased NO production through eNOS activation [56]. In line with previous studies, Mota et al., [57], showed that acute RT promoted endotheliumdependent vasodilatation, eNOS phosphorylation and endothelial production of $\mathrm{NO}$ in the superior mesenteric artery of healthy rats, and the magnitude of these vascular endothelium adjustments were strongly related to the RT intensity. Furthermore, Fontes et al., [58] showed RT-induced enhanced insulin vasodilatation through both PI3K/eNOS and MAPK/ET-1 pathways evaluated by vascular reactivity of mesenteric artery.

A meta-analysis published by Cornelissen and Fagard [59] comprising 12 studies and 341 participants showed no significant reduction from -3.2 to $-3.5 \mathrm{mmHg}$ in resting mean $\mathrm{BP}$ in humans subjected to long-term RT. The same group of authors in another meta-analysis showed that both moderate-intensity dynamic RT and low-intensity isometric RT may reduce mean BP in subjects with optimal pressure and/or prehypertension [60]. However, the mechanism of such adaptations is still unknown.

In 2005, we observed reduction in the diastolic $\mathrm{BP}$ values in normotensive rats subjected to 8 weeks of RT at $70 \%$ of 1 RM. After that, in 2008, Pinter et al., [42] showed a reduction in both systolic and diastolic BP in rats trained at $75 \%$ of $1 \mathrm{RM}$ but not when trained at $60 \%$ of $1 \mathrm{RM}$. In a model of hypertension induced by L-NAME, Araujo et al., [9] showed that RT prevented the increase in mean and diastolic BP evaluated, and 
maintained the arterial luminal-media ratio and total area of arteries' diameter. Recent findings suggested that the changes caused by RT are related to adjustments favoring augmented endothelial $\mathrm{NO}$ bioavailability and reduction of sympathetic vascular modulation [61]. In concert with the findings described above, Mota et al., [62] showed the effectiveness of RT to treat endothelial dysfunction and prevent an increase in arterial BP in type 1 diabetic rats. Karimian et al. [63] showed increased plasma angiogenic factors such as NO in diabetic rats after RT.

\section{Other animal models of RT}

Basically there are two different models to perform aerobic training in rats: running on a treadmill or wheel, and swimming [64-66]. In contrast, among different models of the RT, climb a vertical ladder [67] or jump in a water tank with the load apparatus attached to the tail [68], are RT models most commonly used in animals to study the cardiovascular system after the model by Tamaki et al. [2].

De Souza et al., [67], using the climbing a vertical ladder model, showed that RT promoted a 35\% increase in $\mathrm{CH}, 17 \%$ in left ventricular thickness, $3 \%$ in left ventricular internal diameter and $27 \%$ in cross-sectional area of cardiomyocyte. Using the same model, Souza et al., [69] observed an increase in the aortic wall thickness, an increase elastic lamina and collagen fibers, and the thickness of collagen fibrils in trained rats. In this model, it was showed that RT reduced cardiac dysfunction in rats with diabetes [70] and in infarcted animals [71]. Furthermore, RT was associated to better metalloproteinases-2 activity in the left ventricle, systolic and diastolic BP in high-fat fed rats and to prevents obesity-induced cardiovas- cular disorders, including an increase in mean arterial pressure, sympathetic modulation and impaired baroreflex sensitivity $[72,73]$. In addition, this model of RT has been shown to be effective in cardiac autonomic adaptations in healthy and SHR rats $[74,75]$, to prevent chronic elevation in systolic BP in severe hypertension [76] and to improves hemodynamic status in diabetic ovariectomized rats [77].

On the other hand, fewer studies have used the models of jumping in the water to understand the cardiovascular adaptations. Junqueira et al., [68], showed increased left ventricular collagen density with no changes in proteins responsible for the calcium transport in the myocardial. McCulloch et al., [78], showed that the voluntary and forced jumping into water does not change the magnitude of the cardiovascular responses as such as immediate and substantial bradycardia [79]. However, using this model, RT did not reverse alterations in cardiac structure and function after pathological cardiac hypertrophy and injury induced by nandrolone administration [80].

Although some results were in agreement with findings with Tamaki Model, we cannot rule out the aerobic component, lack of similarity to the protocols performed by humans and also the poor standardization used in these animal models.

\section{Conclusion}

Based on our own findings and those reported by others, the RT model developed by Tamaki et al. [2] seems to be a good and appropriate model for studying cardiovascular adaptations. For the next step, we are studying the molecular mechanisms, mainly microRNAs, that mediate cardiac and vascular adaptations by RT.

Table 1. Cardiovascular adaptations induced by resistance training in animal models

\begin{tabular}{|c|c|c|c|c|c|}
\hline Author & Target tissue & Duration & Intensity & Model & year \\
\hline McCulloch et al. & Cardiac & 5 weeks & No & Jumping into water & 1990 \\
\hline Barauna et al. & Cardiac $\backslash$ Vascular & 4 weeks & $65-75 \%$ of $1 R M$ & Squat-training & 2005 \\
\hline Barauna et al. & Cardiac & For 1,2 and 3 months & $65-75 \%$ of $1 \mathrm{RM}$ & Squat-training & 2007 \\
\hline Barauna et al. & Cardiac & 8 weeks & $65-75 \%$ of $1 R M$ & Squat-training & 2008 \\
\hline Pinter et al. & Cardiac $\backslash$ Vascular & 8 weeks & $60 \%$ and $75 \%$ of $1 \mathrm{RM}$ & Squat-training & 2008 \\
\hline Lizardo et al & Vascular & Acute & $70 \%$ of $1 \mathrm{RM}$ & Squat-training & 2008 \\
\hline Faria et al. & Vascular & Acute & $50 \%$ of $1 R M$ & Squat-training & 2010 \\
\hline McCulloch et al. & Cardiac \vascular & 5 weeks & No & Jumping into water & 2010 \\
\hline Melo et al. & Cardiac & Acute & $80 \%$ of $1 \mathrm{RM}$ & Squat-training & 2011 \\
\hline Soufi et al. & Cardiac & 8 weeks & $70 \%$ of $1 \mathrm{RM}$ & Squat-training & 2011 \\
\hline Yousef et al. & Cardiac \vascular & 4 weeks & $70 \%$ of $1 \mathrm{RM}$ & Squat-training & 2011 \\
\hline Yousef et al. & Cardiac \vascular & 4 weeks & $70 \%$ of $1 \mathrm{RM}$ & Squat-training & 2011 \\
\hline Tanno & Cardiac & 6 weeks & $50-70 \%$ body mass & Jumping into water & 2011 \\
\hline Doustar et al. & Cardiac & 4 weeks & $70 \%$ of $1 \mathrm{RM}$ & Squat-training & 2012 \\
\hline Ahmadiasl et al. & Cardiac & For 1 and 3 months & $70 \%$ of $1 \mathrm{RM}$ & Squat-training & 2012 \\
\hline De Deus et al. & Cardiac \vascular & 10 weeks & $75 \%$ body mass & Vertical ladder & 2012 \\
\hline Araujo et al. & Vascular & 4 weeks & $50 \%$ of $1 \mathrm{RM}$ & Squat-training & 2013 \\
\hline Mostarda et al. & Cardiac & 10 weeks & $40-50 \%$ of $1 R M$ & Squat-training & 2013 \\
\hline
\end{tabular}




\begin{tabular}{|c|c|c|c|c|c|}
\hline Author & Target tissue & Duration & Intensity & Model & year \\
\hline Leite et al. & Cardiac \vascular & 3 months & $75 \%$ body mass & Vertical ladder & 2013 \\
\hline Fontes et al. & Vascular & Acute & $70 \%$ of $1 \mathrm{RM}$ & Squat-training & 2014 \\
\hline Alves et al. & Cardiac \vascular & 8 weeks & $65-75 \%$ of $1 R M$ & Squat-training & 2014 \\
\hline Mota et al. & Vascular & 8 weeks & $50 \%$ of $1 \mathrm{RM}$ & Squat-training & 2014 \\
\hline Grans et al. & Cardiac \vascular & 3 months & $75 \%$ body mass & Vertical ladder & 2014 \\
\hline Sanches et al. & Cardiac \vascular & 8 weeks & $75 \%$ body mass & Vertical ladder & 2014 \\
\hline De Souza & Cardiac & 8 weeks & $50 \%$ body mass & Vertical ladder & 2014 \\
\hline Melo et al. & Cardiac & 8 weeks & $80 \%$ of $1 R M$ & Squat-training & 2015 \\
\hline Fernandes et al. & Vascular & Acute & $50 \%$ of $1 R M$ & Squat-training & 2015 \\
\hline Mota et al. & Vascular & Acute & 30,50 and $70 \%$ of $1 \mathrm{RM}$ & Squat-training & 2015 \\
\hline Tharciano et al. & Vascular & Acute & $40 \%$ of $1 \mathrm{RM}$ & Squat-training & 2015 \\
\hline Ghiasi et al. & Cardiac & For 1 and 4 months & $70 \%$ of $1 \mathrm{RM}$ & Squat-training & 2015 \\
\hline Quinteiro et al. & Vascular & 8 weeks & $\%$ of $1 R M$ & Vertical ladder & 2015 \\
\hline Lima et al. & Cardiac \vascular & 4 weeks & $75 \%$ body mass & Jumping into water & 2015 \\
\hline Macedo et al. & Vascular & Acute & $40 \%$ of $1 \mathrm{RM}$ & Squat-training & 2016 \\
\hline Speretta et al. & Cardiac \vascular & 10 weeks & $75 \%$ body mass & Vertical ladder & 2016 \\
\hline Neves et al. & Vascular & 3 months & $75 \%$ body mass & Vertical ladder & 2016 \\
\hline Junqueira et al. & Cardiac & 10 weeks & $50 \%$ body mass & Jumping into water & 2016 \\
\hline Speretta et al. & Cardiac \vascular & 10 weeks & $75 \%$ body mass & Vertical ladder & 2016 \\
\hline Cunha et al. & Cardiac & 5 weeks & $50-70 \%$ body mass & Jumping into water & 2016 \\
\hline Faria et al. & Vascular & Acute & $50 \%$ of $1 \mathrm{RM}$ & Squat-training & 2017 \\
\hline Hentschke et al. & Cardiac \vascular & 8 weeks & $65-75 \%$ of $1 \mathrm{RM}$ & Squat-training & 2017 \\
\hline Souza et al. & Vascular & 12 weeks & $75 \%$ body mass & Vertical ladder & 2017 \\
\hline Macedo et al. & Vascular & 8 weeks & $40 \%$ of $1 \mathrm{RM}$ & Squat-training & 2017 \\
\hline Gomes et al. & Cardiac & 8 weeks & $75 \%$ body mass & Vertical ladder & 2017 \\
\hline Rashidlamir et al. & Cardiac & 8 weeks & $30 \%$ of $1 R M$ & Vertical ladder & 2017 \\
\hline Barretti et al & Cardiac & 8 weeks & $80 \%$ of $1 \mathrm{RM}$ & Squat-training & 2017 \\
\hline
\end{tabular}

\section{Acknowledgements}

CAPES-Proex. Melo SFS is the recipient of a FAPES-DCR ( $\mathrm{n}^{\circ}$ 74088009-DCR). This work was supported by Oliveira EM CNPq-Fellowship (No. 308 267/2013-3), Barauna VG CNPq-Universal (no 424070 /2016-2), FAPES-Universal (no 67659551) and FAPESP (no 07/52457-3; 10/09438-0).

\section{Competing Interests}

The authors have declared that no competing interest exists.

\section{References}

1. Wirth O, Gregory EW, Cutlip RG, Miller GR. Control and quantitation of voluntary weight-lifting performance of rats. J Appl Physiol. 2003;95:402-12.

2. Tamaki T, Uchiyama S, Nakano S. A weight-lifting exercise model for inducing hypertrophy in the hindlimb muscles of rats. Med Sci Sports Exerc. 1992;24:881-6.

3. Klitgaard $\mathrm{H}$. A model for quantitative strength training of hindlimb muscles of the rat. J Appl Physiol. 1988;64:1740-5.

4. Nicastro H, Zanchi NE, Da Luz CR, Chaves DFS, Lancha AH. An experimental model for resistance exercise in rodents. J Biomed Biotechnol. 2012;2012:1-7.

5. Drummond LR, Del Carlo RJ, Melo SFS, Carneiro-Júnior MA, Silva KA, Soares RA $C$ et al. Enhanced femoral neck strength in response to weightlifting exercise training in maturing male rats. Int Sport J. 2013;14(3):155-67.

6. Notomi T, Lee SJ, Okimoto N, Okazaki Y, Takamoto T, Nakamura T, et al. Effects of resistance exercise training on mass, strength, and turnover of bone in growing rats. Eur J Appl Physiol. 2000;82:268-74

7. Yaspelkis BB, Singh MK, Trevino B, Krisan AD, Collins D E. Resistance training increases glucose uptake and transport in rat skeletal muscle. Acta Physiol Scand. 2002;175:315-23.

8. Panveloski-Costa AC, Pinto Júnior DAC, Brandão BB, Moreira RJ, Machado UF, Seraphim PM. Resistive training reduces inflammation in skeletal muscle and improves the peripheral insulin sensitivity in obese rats induced by hyperlipidic diet. Arq Bras Endocrinol Metabol. 2011;55(2):155-63.

9. Araujo AJS, Santos ACV, Souza KDS, Aires MB, Santana-Filho VJ, Fioretto ET, et al. Resistance Training Controls Arterial Blood Pressure in Rats with L-NAME- Induced Hypertension. Arq Bras Cardiol. 2013;339-46.

10. Do Carmo EC, Bueno Junior CR, Fernandes T, Barreti DLM, Melo SFS, Silva-Junior N. et al. The Role of Anabolic Steroids on Hypertrophy and
Muscular Strength in Aerobic Resistance and Strength Training. Rev Bras Med do Esporte. 2011;17(3):212-7.

11. Melo SFS, Fernandes T, Baraúna VG, Matos KC, Santos AAS, Tucci PJF, et al. Expression of MicroRNA-29 and collagen in cardiac muscle after swimming training in myocardial-infarcted rats. Cell Physiol Biochem. 2014;33(3):657-69.

12. Hill JA, Olson EN. Cardiac plasticity. N Engl J Med. 2008;358:1370-80.

13. Soci UPR, Melo SFS, Gomes JLP, Silveira AC, Nóbrega C, Oliveira EM . Exercise Training and Epigenetic Regulation: Multilevel Modification and Regulation of Gene Expression. In: Exercise for Cardiovascular Disease Prevention and Treatment. Advances in Experimental Medicine and Biology, 1ed. Germany: Springer Singapore; 2017: 281-322.

14. Bernardo BC, Weeks KL, Pretorius L, McMullen JR. Molecular distinction between physiological and pathological cardiac hypertrophy: Experimental findings and therapeutic strategies. Pharmacology and Therapeutics. 2010:191-227.

15. Chelliah RK, Senior R. Pathological and physiological left ventricular hypertrophy: echocardiography for differentiation. Future Cardiol. 2009;5:495-502.

16. Rawlins J, Bhan A, Sharma S. Left ventricular hypertrophy in athletes. Eur J Echocardiogr. 2009;10:350-6.

17. Barauna VG, Junior MLB, Costa Rosa LFBP, Casarini DE, Krieger JE, Oliveira EM. Cardiovascular adaptations in rats submitted to a resistance-training model. Clin Exp Pharmacol Physiol. 2005;32:249-54.

18. Van den Broeke C, Fagard R. Left ventricular structure and function, assessed by imaging and Doppler echocardiography, in athletes engaged in throwing events. Int J Sports Med. 1988;9:407-11.

19. Brown SP, Thompson WR. Standardization indices of cardiac hypertrophy in weight lifters. J Sports Sci. 1987;5:147-53.

20. Pluim BM, Zwinderman AH, van der Laarse A, van der Wall EE. The athlete's heart. A meta-analysis of cardiac structure and function. Circulation. 2000;101:336-44.

21. Fagard RH. Athlete's heart: a meta-analysis of the echocardiographic experience. Int J Sports Med. 1996;17 Suppl 3:S140-4.

22. Barauna VG, Rosa KT, Irigoyen MC, de Oliveira EM. Effects of resistance training on ventricular function and hypertrophy in a rat model. Clin Med Res. 2007;5:114-20.

23. Melo STF, Barauna VG, Carneiro Júnior MA, Bozi LHM, Drummond LR, Natali AJ, et al. Resistance Training Regulates Cardiac Function through Modulation of miRNA-214. Int J Mol Sci. 2014:1-6

24. Hunyady L, Catt KJ. Pleiotropic AT1 receptor signaling pathways mediating physiological and pathogenic actions of angiotensin II. Mol Endocrinol. 2006;20:953-70.

25. Barauna VG, Magalhaes FC, Krieger JE, Oliveira EM. AT1 receptor participates in the cardiac hypertrophy induced by resistance training in rats. Am J Physiol Regul Integr Comp Physiol. 2008;295:R381-7.

26. Zou Y, Akazawa H, Qin Y, Sano M, Takano H, Minamino T, et al. Mechanical stress activates angiotensin II type 1 receptor without the involvement of angiotensin II. Nat Cell Biol. 2004;6:499-506. 
27. Yasuda $\mathrm{N}$, Akazawa $\mathrm{H}$, Oin $\mathrm{Y}$, Zou $\mathrm{Y}$, Komuro I. A novel mechanism of mechanical stress-induced angiotensin II type 1-receptor activation without the involvement of angiotensin II. Naunyn-Schmiedeberg's Archives of Pharmacology. 2008:393-9.

28. Frank D, Kuhn C, Brors B, Hanselmann C, Lüdde M, Katus HA, et al. Gene expression pattern in biomechanically stretched cardiomyocytes: Evidence for a stretch-specific gene program. Hypertension. 2008;51:309-18.

29. Zhai P, Yamamoto M, Galeotti J, Liu J, Masurekar M, Thaisz J, et al. Cardiac-specific overexpression of AT1 receptor mutant lacking G aq/Gai causes hypertrophy and bradycardia in transgenic mice. J Clin Invest. 2005;115:3045-56.

30. Violin JD, Soergel DG, Lark MW. Beta-arrestin-biased ligands at the AT1R: a novel approach to the treatment of acute heart failure. Drug Discov Today Ther Strateg. 2014;10(2):1-6.

31. Melo SFS, Barauna VG, Fernandes T, Carmo EC, Oliveira CR, et al. Cardiac AT1 receptor-dependent and IGF1 receptor-independent signaling is activated by a single bout of resistance exercise. Physiol Res. 2017;66(6):1061-1065

32. Luo J, McMullen JR, Sobkiw CL, Zhang L, Dorfman AL, Sherwood MC, et al. Class IA phosphoinositide 3-kinase regulates heart size and physiological cardiac hypertrophy. Mol Cell Biol. 2005;25:9491-502.

33. Neri Serneri GG, Boddi M, Modesti PA, Cecioni I, Coppo M, Padeletti L, et al Increased cardiac sympathetic activity and insulin-like growth factor-I formation are associated with physiological hypertrophy in athletes. Circ Res. 2001;89:977-82.

34. Scheinowitz M, Kessler-Icekson G, Freimann S, Zimmermann R, Schaper W, Golomb E, et al. Short- and long-term swimming exercise training increases myocardial insulin-like growth factor-I gene expression. Growth Horm IGF Res. 2003;13:19-25.

35. Kim J, Wende AR, Sena S, Theobald HA, Soto J, Sloan C, et al. Insulin-like growth factor I receptor signaling is required for exercise-induced cardiac hypertrophy. Mol Endocrinol. 2008;22:2531-43.

36. Melo SFS, Amadeu MA, Magalhães F de C, Fernandes T, Carmo EC do, Barretti DLM, et al. Activation of AKT-mTor signaling pathways by angiotensin II receptor type 1 after a session of strength exercise in cardiac muscle of rats. Brazilian Journal of Physical Education and Sport 2011;25(3):377-85.

37. Bueno OF, De Windt LJ, Tymitz KM, Witt SA, Kimball TR, Klevitsky R, et al. The MEK1-ERK1/2 signaling pathway promotes compensated cardiac hypertrophy in transgenic mice. EMBO J. 2000;19(23):6341-50.

38. Iemitsu M, Maeda S, Jesmin S, Otsuki T, Kasuya Y, Miyauchi T. Activation pattern of MAPK signaling in the hearts of trained and untrained rats following a single bout of exercise. J Appl Physiol. 2006;101(1):151-63.

39. Nakamura A, Yoshida K, Takeda S, Dohi N, Ikeda SI. Progression of dystrophic features and activation of mitogen-activated protein kinases and calcineurin by physical exercise, in hearts of $\mathrm{mdx}$ mice. FEBS Lett. 2002;520(1-3):18-24.

40. Melo SFS, Baraúna VG, Neves VJ, Fernandes T, Lara LS, Mazzotti DR, et al. Exercise training restores the cardiac microRNA-1 and 214 levels regulating $\mathrm{Ca}^{2}+$ handling after myocardial infarction. BMC Cardiovascular Disorders. 2015; 15(166):1-8

41. Bers DM. Cardiac excitation-contraction coupling. Nature. 2002;415(6868):198205

42. Pinter RCCE, Padilha AS, de Oliveira EM, Vassallo DV, Lizardo JHF. Cardiovascular adaptive responses in rats submitted to moderate resistance training. Eur J Appl Physiol. 2008;103(5):605-13.

43. Fernandes AA, Faria TO, Ribeiro, Júnior RF , Costa GP, Marchezini B, et al. A single resistance exercise session improves myocardial contractility in spontaneously hypertensive rats. Braz J Med Biol Res. 2015;48.

44. Alves JP, Nunes RB, Stefani GP, Dal Lago P. Resistance training improves hemodynamic function, collagen deposition and inflammatory profiles: Experimental model of heart failure. PLoS One. 2014;9(10).

45. Doustar Y, Soufi FG, Jafary A, Saber MM, Ghiassie R. Role of four-week resistance exercise in preserving the heart against ischaemia-reperfusioninduced injury : cardiovascular topic. Cardiovasc J Afr. 2012;23(8):451-5.

46. Soufi FG, Saber MM, Ghiassie R, Alipour M. Role of 12-week resistance training in preserving the heart against ischemia-reperfusion-induced injury. Cardiol J. 2011;18(2):140-5

47. Barretti DLM, Melo SFS, Oliveira EM, Barauna VG. Resistance training attenuates salt overload-induced cardiac remodeling and diastolic dysfunction in normotensive rats. Brazilian J Med Biol Res. 2017;50(9):1-7.

48. Mostarda CT, Rodrigues B, de Moraes OA, Moraes-Silva IC, Arruda PB, Cardoso $\mathrm{R}$, et al. Low intensity resistance training improves systolic function and cardiovascular autonomic control in diabetic rats. J Diabetes Complications. 2014;28(3):273-8.

49. Queiroz ACC, Sousa JCS, Cavalli AA, Silva ND, Costa LR, Tobaldini E, et al. Post-resistance exercise hemodynamic and autonomic responses: Comparison between normotensive and hypertensive men. Scand J Med Sci Sports. 2014;1-9.

50. Teixeira L, Ritti-Dias RM, Tinucci T, Mion D, De Moraes Forjaz CL. Post-concurrent exercise hemodynamics and cardiac autonomic modulation. Eur J Appl Physiol. 2011;111(9):2069-78.

51. Queiroz AC, Gagliardi JF, Forjaz CL, Rezk CC. Clinic and ambulatory blood pressure responses after resistance exercise. J Strength Cond Res. 2009;23(2):571-8
52. Melo CM, Alencar Filho AC, Tinucci $\mathrm{T}$, Mion $\mathrm{D}$, Forjaz CLM. Postexercise hypotension induced by low-intensity resistance exercise in hypertensive women receiving captopril. Blood Press Monit. 2006;11:183-9.

53. Mota MR, Pardono E, Lima LC, Arsa G, Bottaro M, Campbell CS, et al. Effects of treadmill running and resistance exercises on lowering blood pressure during the daily work of hypertensive subjects. J Strength Cond Res. 2009;23(8):2331-8

54. Jannig PR, Cardoso AC, Fleischmann E, Coelho CW D carvalho T. Influence of resistance exercises order performance on post-exercise hypotension in hypertensive elderly. Rev Bras Med Esporte. 2009;15(5):338-41.

55. Faria TDO, Targueta GP, Angeli JK, Almeida EAS, Stefanon I, Vassallo DV, et al. Acute resistance exercise reduces blood pressure and vascular reactivity, and increases endothelium-dependent relaxation in spontaneously hypertensive rats. Eur J Appl Physiol. 2010;110(2):359-66.

56. Faria TO, Angeli JK, Mello LGM, Pinto GC, Stefanon I, Vassallo DV, et al. A Single Resistance Exercise Session Improves Aortic Endothelial Function in Hypertensive Rats. Arq Bras Cardiol. 2017;108(3):228-36.

57. Mota MM, Mesquita TR, Silva TL, Fontes MT, Lauton Santos S, Capettini Ldos $S$, et al. Endothelium adjustments to acute resistance exercise are intensity-dependent in healthy animals. Life Sci. 2015;1(42):86-91.

58. Fontes MT, Silva TLBT, Mota MM, Barreto AS, Rossoni L V, Santos MR V. Resistance exercise acutely enhances mesenteric artery insulin-induced relaxation in healthy rats. Life Sci. 2014;94(1):24-9.

59. Cornelissen VA, Fagard RH. Effect of resistance training on resting blood pressure: a meta-analysis of randomized controlled trials. J Hypertens. 2005;23(2):251-259.

60. Cornelissen VA, Fagard RH, Coeckelberghs E, Vanhees L. Impact of resistance training on blood pressure and other cardiovascular risk factors: a meta-analysis of randomized, controlled trials. Hypertension. 2011;58(5):950-8.

61. Macedo FN, Mesquita TR, Melo VU, Mota MM, Silva TL, Santana MN, et al. Increased Nitric Oxide Bioavailability and Decreased Sympathetic Modulation Are Involved in Vascular Adjustments Induced by Low-Intensity Resistance Training. Front Physiol Front Physiol. 2016;7(7):2653389-265.

62. Mota MM, Silva TL, Fontes MT, Barreto AS, Araújo JE, Oliveira AC, et al. Resistance exercise restores endothelial function and reduces blood pressure in type 1 diabetic rats. Arq Bras Cardiol. 2014;103 (1):25-32.

63. Karimian J, Khazaei M, Shekarchizadeh P. Effct of Resistance Training on Capillary Density Around Slow and Fast Twitch Muscle Fibers in Diabetic and Normal Rats. Asian J Sport Med. 2015;6(4).

64. Wisløff U, Loennechen JP, Currie S, Smith GL, Ellingsen. Aerobic exercise reduces cardiomyocyte hypertrophy and increases contractility, $\mathrm{Ca}^{2+}$ sensitivity and SERCA-2 in rat after myocardial infarction. Cardiovascul Res. 2002;54:162-74.

65. Melo SFS, Lunz W, Fontes EPB, Dias CMGC, Júnior MAC, de Moura AG, et al. Different levels of Hsp72 in female rat myocardium in response to voluntary exercise and forced exercise. Arq. Bras. Cardiol. 2009; 93: 456-462.

66. Musch TI, Moore RL, Leathers DJ, Bruno A, Zelis R. Endurance training in rats with chronic heart failure induced by myocardial infarction. Circulation. 1986;74(2):431-41.

67. De Souza MR, Pimenta L, Pithon-Curi TC, Bucci M, Fontinele RG, De Souza RR. Effects of aerobic training, resistance training, or combined resistance-aerobic training on the left ventricular myocardium in a rat model. Microsc Res Tech. 2014;77(9):727-34

68. Junqueira A, Cicogna AC, Engel LE, Aldá MA, de Tomasi LC, Giuffrida R, et al. Effects of Growth Hormone on Cardiac Remodeling During Resistance Training in Rats. Arq Bras Cardiol. 2016;106(1):18-25

69. Souza RR, de França E, Madureira D, Pontes CCR, Santana JO, Caperuto EC. Resistance training improves aortic structure in Wistar rats. Brazilian J Phys Ther. 2017;

70. Quinteiro H, Buzin M, Conti FF, Dias DDS, Figueroa D, Llesuy S, et al. Aerobic exercise training promotes additional cardiac benefits better than resistance exercise training in postmenopausal rats with diabetes. Menopause. 2014;22(5):1-8.

71. Grans CF, Feriani DI, Abssamra MEV, Rocha LY, Carrozzi NM, Mostarda C, et al. Resistance training after myocardial infarction in rats: its role on cardiac and autonomic function. Arq Bras Cardiol. 2014;103(1):60-8.

72. Leite RD, Durigan RDCM, De Souza LAD, De Souza MVC, Souza MDG, Selistre-De-Araujo HS, et al. Resistance training may concomitantly benefit body composition, blood pressure and muscle MMP-2 activity on the left ventricle of high-fat fed diet rats. Metabolism. 2013;62(10):1477-84

73. Speretta GF, Silva AA, Vendramini RC, Zanesco A, Delbin MA, Menani JV, Bassi M, Colombari E CD. Resistance training prevents the cardiovascular changes caused by high-fat diet. Life Sci. 2016;1(46):154-62

74. Gomes MFP, Borges ME, Rossi VA, Moura EOC Medeiros A. The Effect of Physical Resistance Training on Baroreflex Sensitivity of Hypertensive Rats. Arq Bras Cardiol. 2017;108(6):539-45.

75. de Deus AP, de Oliveira CR, Simões RP, Baldissera V, da Silva CA, Rossi BRO, et al. Metabolic and cardiac autonomic effects of high-intensity resistance training protocol in Wistar rats. J Strength Cond Res.2012;26(3):618-24.

76. Neves RV, Souza MK, Passos CS, Bacurau RF, Simoes HG, Prestes J, Boim MA, Câmara NO, Franco MD MM. Resistance Training in Spontaneously Hypertensive Rats with Severe Hypertension. Arq Bras Cardiol. 2016;106(3):201-209. 
77. Sanches IC, Conti FF, Sartori M, Irigoyen MC, De Angelis K. Standardization of resistance exercise training: Effects in diabetic ovariectomized rats. Int J Sports Med. 2014;35(4):323-9.

78. McCulloch PF, Dinovo KM, Connolly TM. The cardiovascular and endocrine responses to voluntary and forced diving in trained and untrained rats. Am J Physiol Regul Integr Comp Physiol. 2010;298(1):R224-34.

79. McCulloch PF, Jones DR. Cortical Influences on Diving Bradycardia in Muskrats (Ondatra zibethicus). Physiol Zool. 1990;63(6):1098-117.

80. Lima EM, Nascimento AM, Brasil GA, Kalil IC, Lenz D, Endringer DC, et al. Cardiopulmonary reflex, cardiac cytokines, and nandrolone decanoate: response to resistance training in rats. Can J Physiol Pharmacol. 2015;93(11):985-91. 